Part of Journal of Research of the National Bureau of Standards, Volume 25, August 1940

\title{
EFFECT OF OXYGEN AND MOISTURE ON THE STABILITY OF LEATHER AT ELEVATED TEMPERATURES
}

\author{
By Joseph R. Kanagy
}

\section{ABSTRACT}

A commercial leather and leathers tanned with sumac, chestnut, quebracho, cutch, and a blend of chestnut, sulfited quebracho, and cutch, were heated to temperatures from $67^{\circ}$ to $130^{\circ} \mathrm{C}$ in helium, in air, and in oxygen, at atmospheric pressure in the absence of water vapor. The effect of varying the concentration of water vapor was studied with chestnut and quebracho leathers at $100^{\circ} \mathrm{C}$. The loss of tensile strength and the increase in the nitrogenous materials extractable in $0.1 \mathrm{~N}$ sodium carbonate solution were used as measures of the deterioration, the former being regarded as the more reliable. Raising the temperature increased the deterioration under all circumstances. In air, deterioration was more rapid than in the inert gas (helium), and in oxygen it was more rapid than in air. The logarithm of the fractional deterioration of the dry leather increased linearly with the duration of heating in air. The effect of humidity was small for samples having a $\mathrm{pH}$ greater than 3 but increased rapidly at lower values of the $\mathrm{pH}$. The most important features of an accelerated-aging test for leather are an elevated temperature and an oxidizing atmosphere containing moisture.

\section{CONTENTS}

I. Introduction Page

1. Introduction _..

II. Apparatus and materials . .

III. Procedure _.

IV. Experimental results and discussion

1. Effect of temperature and atmosphere

2 . Effect of duration of exposure

3. Effect of varying the humidity

V. Conclusions 159

\section{INTRODUCTION}

For the past few years, a series of investigations has been in progress at the National Bureau of Standards relating to the various factors which affect the aging qualities of leather. In the course of that work, ${ }^{1,2}$ to develop a suitable accelerated aging test, leather aged under normal conditions was compared with similar leather aged at elevated temperatures in an atmosphere of oxygen under pressure in a bomb. When vegetable-tanned leather was exposed in an oxygen bomb under the accelerated-aging conditions, the deterioration paralleled that obtained during normal aging with respect to change of rate of deterioration with $\mathrm{pH}^{3}$ and the influence of the tanning materials on the stability of the leather. The effects of varying the atmosphere, time, temperature, and moisture contents were also studied.

1 J. Research NBS 18, 713 (1937) RP1004; J. Am. Leather Chem. Assn. 32, 314 (1937).

2 J. Research NBS 21, 241 (1938) RP1128; J. Am. Leather Chem. Assn. 33, 565 (1938).

3 J. Am. Leather Chem. Assn. 30, 370 (1935). 
Although aging of leather in the bomb showed considerable promise as an accelerated-aging test, several disadvantages of using this method were evident. The operation of a test under pressure requires special equipment, and the deterioration in the bomb was not caused entirely by the oxygen and elevated temperature but also by the moisture which was formed from the oxidation of the tanning materials. This factor could not be conveniently controlled and made it difficult to compare the aging quality of a vegetable-tanned leather with a leather, such as chrome, which contains no oxidizable tanning materials.

In the present investigation a different apparatus was designed and a method of aging used which is believed to be an improvement over aging in the bomb. Further results were obtained on the effects of the various factors which influence the aging qualities of leather, and the essential features of an accelerated-aging test are more definitely established.

\section{APPARATUS AND MATERIALS}

The apparatus used in making the tests is shown in figure 1. The exposure chamber consists of a brass cylinder $7 \mathrm{in}$. in diameter and

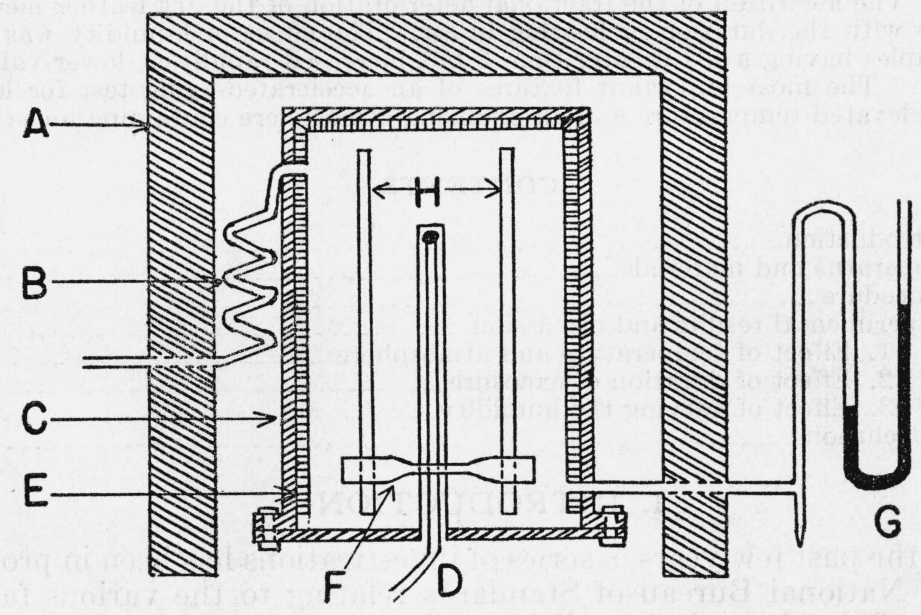

FigURe 1.-Apparatus used in aging the leathers.

$A$, oven; $B$, pre-heating coil; $C$, exposure chamber; $D$, thermocouple; $E$, asbestos lining; $F$, leather sample; $G$, flowmeter; $H$, rack.

14 in. long. A removable cover is fitted on one end and fastened with bolts to a flange connected to the cylinder. The inside of the cylinder is lined with asbestos. The temperature inside the chamber is determined by means of a thermocouple placed inside a copper tube which protrudes into the cylinder. Inlet and outlet openings at opposite ends and opposite sides permit the flow of a continuous stream of gas. The rate of flow is determined by means of a flowmeter. A slightly increased pressure is required to operate the flowmeter, and therefore the pressure inside the chamber is about $10 \mathrm{~mm}$ above atmospheric pressure. The gases are preheated before entering the chamber by passing through the coil in the inlet tubing. 
The apparatus used in regulating the amount of moisture in the gas stream is shown in figure 2. It consists of saturators filled with distilled water and placed in a water bath, the temperature of which is controlled within $\pm 0.1^{\circ} \mathrm{C}$ by means of a mercury regulator.

The leathers used in this work were sumac, chestnut, quebracho, cutch, a blend of chestnut, sulfited quebracho, and cutch, and a commercial leather. All except the commercial leather were tanned in the experimental tannery at the National Bureau of Standards.

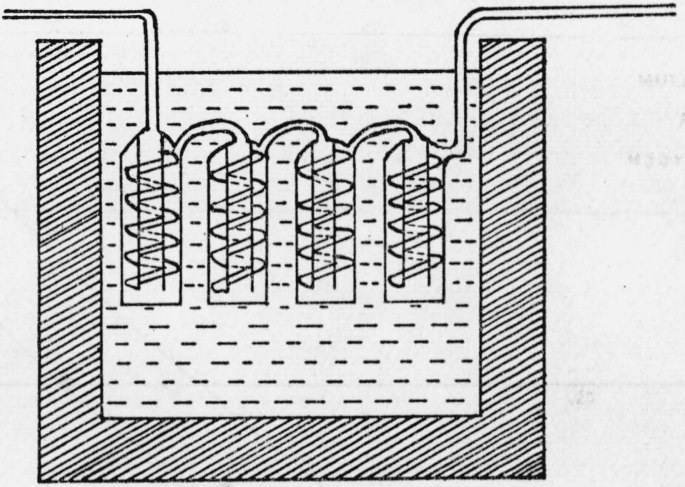

Figure 2.-Water bath and saturators used to regulate the humidity of the gas streams.

\section{PROCEDURE}

Twelve tensile-strength specimens were cut from blocks of the leathers 7 by 14 ins. These were numbered 1 to 12 consecutively. The even-numbered specimens were aged while the odd-numbered ones were used as controls. The samples were laid on racks in the exposure chamber to age. In order to assure uniform moisture contents for the leathers, it was found necessary to introduce an initial drying period. This was done by allowing the samples to condition at the same temperature at which they were to be aged, for 6 hours in a stream of dry gas before placing the cover on the chamber. At the end of this period of time, the cover was placed on the chamber and the flow of gas regulated to 8 to $12 \mathrm{ml} / \mathrm{min}$.

Percentage loss in tensile strength and the percentage of the total nitrogenous materials extractable were used to evaluate the deterioration of the leathers. In recording the results of the tensile-strength measurements, the average value for the six specimens was used in each experiment. All samples were conditioned for 48 hours and tested at 65-percent relative humidity. After the breaking-strength measurements were made, the broken specimens were ground and a determination of the extractable nitrogenous material was made by extracting a sample with a solution of $0.1 \mathrm{~N}$ sodium carbonate. ${ }^{4}$

\section{EXPERIMENTAL RESULTS AND DISCUSSION}

The changes caused by varying the following conditions were studied: the temperature, the gas in contact with the leathers, the acidity of the leathers, the humidity, and the duration of exposure.

4J. Research NBS 17, 247 (1936) RP909; J. Am. Leather Chem. Assn. 32, 12 (1937). 
In all experiments, except those in the study of the effect of duration of exposure, the time of aging was 7 days.

\section{EFFECT OF TEMPERATURE AND ATMOSPHERE}

The leathers were subjected to dry gases at $67^{\circ}$ to $130^{\circ} \mathrm{C}$ to determine the effects of heat and oxidation. These temperatures were the exact readings of the thermocouples inside the exposure chamber and were slightly higher than the thermometer readings of the oven.

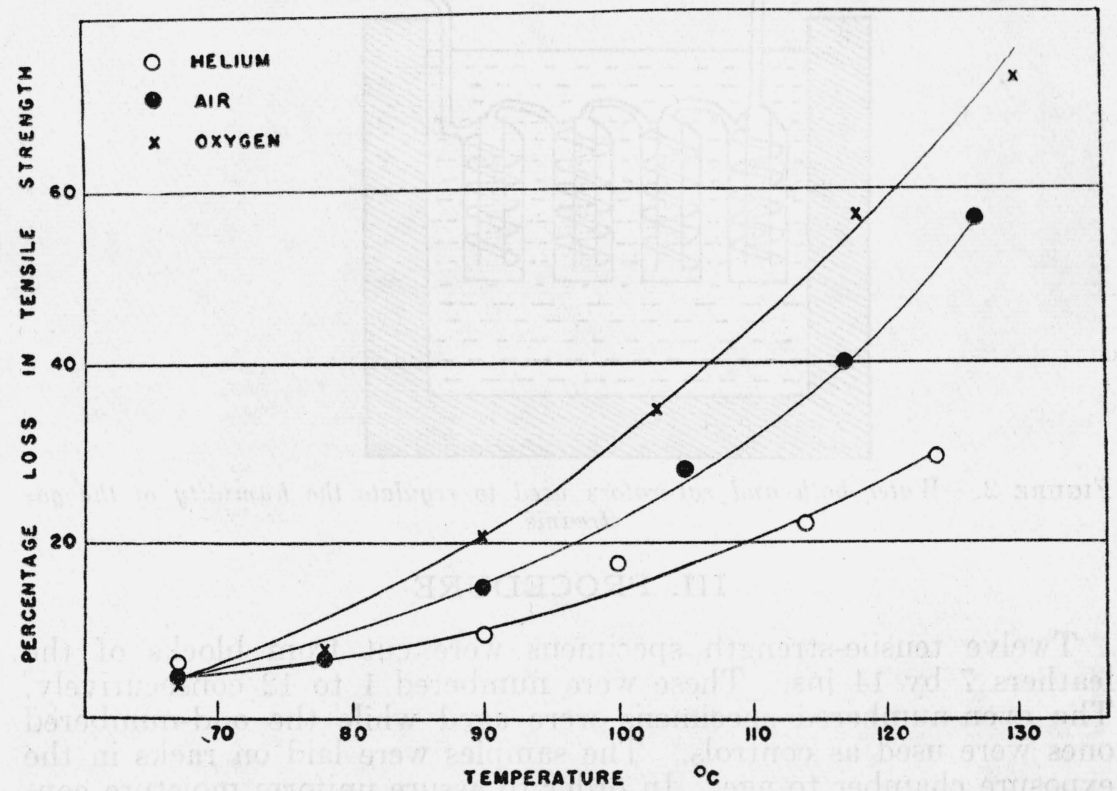

FIGURE 3.-Effect of temperature and aging atmosphere on leather as shown by the percentage loss in tensile strength.

(Average results for all the leathers exposed.)

The study was made by exposing the leathers for 7 days in helium, in air, and in oxygen. The $\mathrm{pH}$ values of all the leather samples were above 3 , and therefore the effect of acidity was negligible. The gases were dried before passing over the leathers, and further precautions to assure dry conditions were taken by placing a dish containing calcium oxide in the exposure chamber. The results are given in table 1 and in figures 3,4 , and 5 . For the purpose of comparing the effects of the three different atmospheres, the results for all the leathers exposed under each condition were averaged and are plotted. in figures 3 and 4 .

Beginning at about $90^{\circ} \mathrm{C}$, a rapid acceleration with increase in temperature may be observed. The deterioration in the presence of the inert helium gas may be considered as that caused by heat alone. 


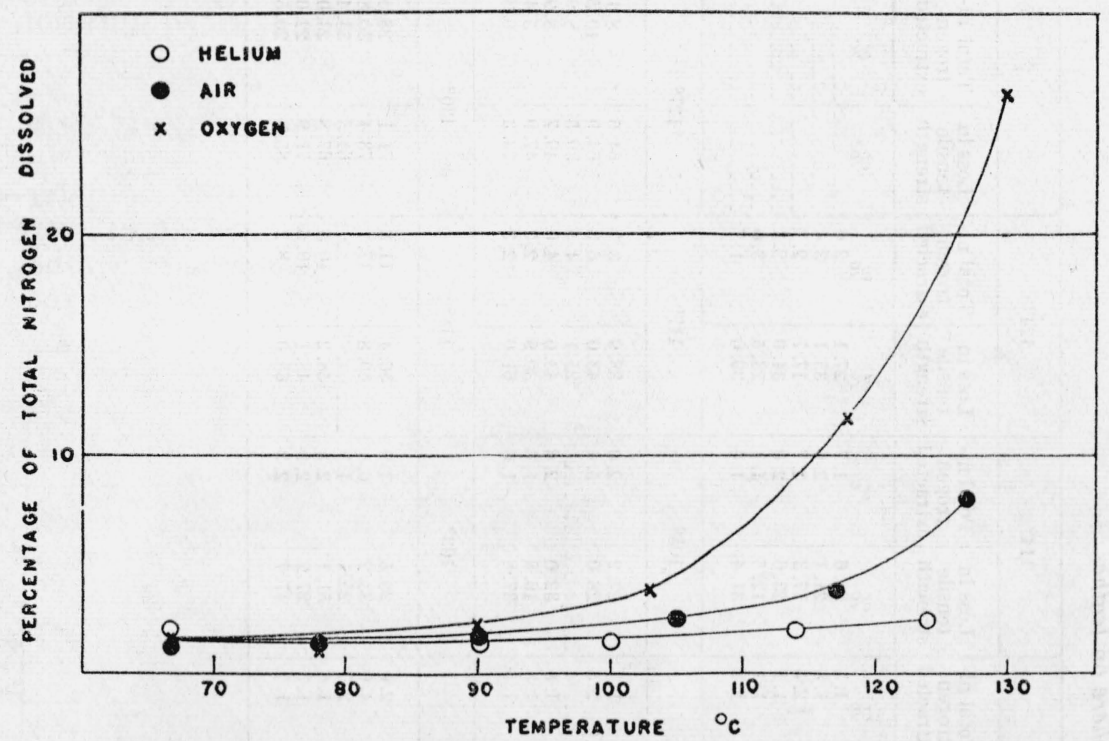

FigURE 4.-Effect of temperature and aging atmosphere on leather as shown by the percentage of the total nitrogen extracted.

(Average results for all the leathers exposed.)

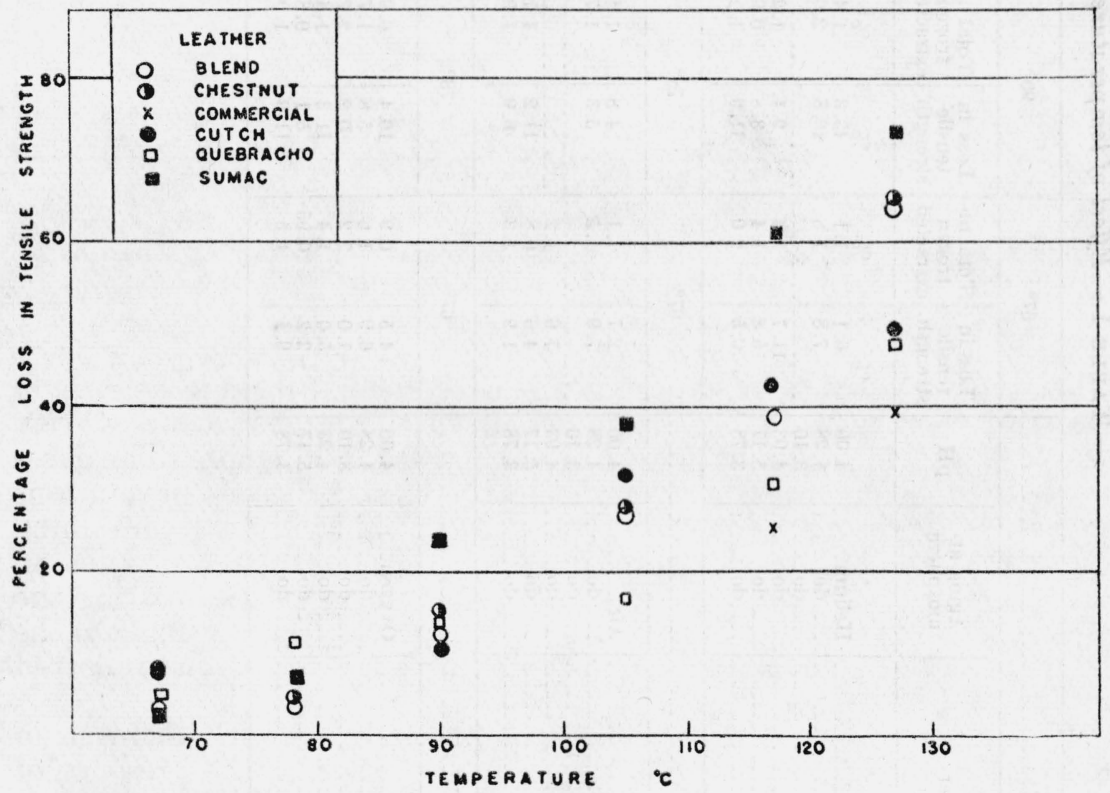

FIGURE 5.-Increase in deterioration with increase in temperature of leathers aged in air. 
TABLE 1.-Effect of temperature and atmosphere on leather

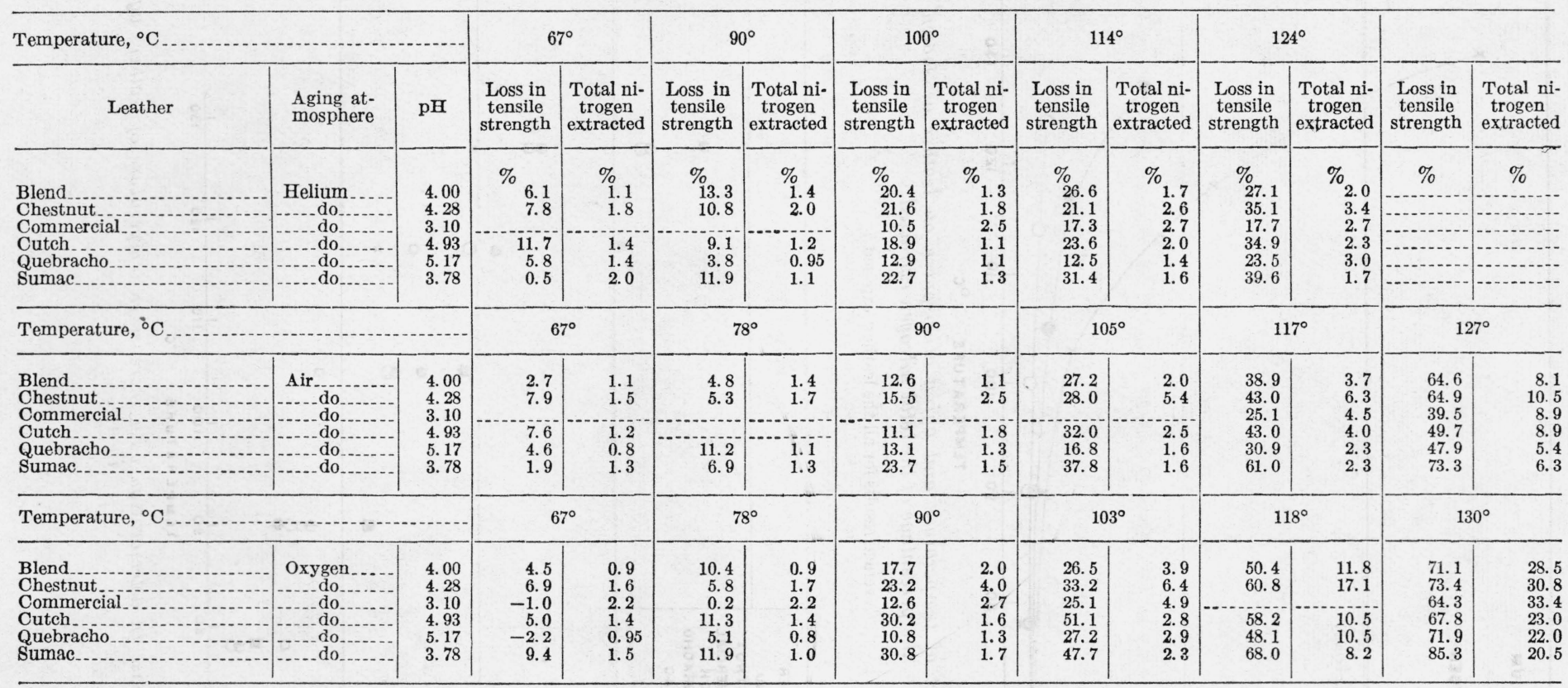

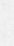


The accelerating effect of oxygen on the deterioration of the leather is clearly shown in figures 3 and 4 , where considerably more deterioration is evident in oxygen or air than in helium. The increased deterioration where oxygen is present is, however, not proportional to the increase in its partial pressure. Similar results were observed in the study of the deterioration occurring in the oxygen bomb. High concentrations of oxygen therefore appear to accelerate deterioration little more than moderate concentrations and the rate of deterioration appears to bemore effectively accelerated by raising the temperature. The loss in tensile strength with increase in temperature for all the leathers aged in an atmosphere of air is shown in figure 5. This figure shows the separation of the points representing the percentage losses in the tensile strength of the leathers, which indicates another advantage of using an elevated temperature for an aging test.

The degree of tannage appears to be an important factor in determining the stability of the leathers under these conditions. Sumac leather, which was least stable, had the lowest degree of tannage, while the commercial and quebracho leathers, which had the highest degrees of tannage, were most stable.

The results for percentage loss in tensile strength and percentage of the total nitrogenous materials dissolved, as shown in table 1, do not give the same comparative values for the stability of the leathers. From the values of the degrees of tannage, from physical examination, and previous results, loss in tensile strength appears to be a more reliable criterion of deterioration than the percentage of the nitrogenous materials extractable.

\section{EFFECT OF DURATION OF EXPOSURE}

The effect of duration of exposure was studied in an atmosphere of dry air at $110^{\circ} \mathrm{C}$ with chestnut- and quebracho-tanned leathers having $\mathrm{pH}$ values above 3.5. The results are shown in figure 6 , where the logarithm of the percentage of tensile strength retained by the leathers after aging is plotted against the time in days. This relation is linear for the dry leathers during the regular aging period. The lines, however, do not coincide at $\log 2$ because of the greater rate of deterioration which occurs during the initial drying period. If it is assumed that the percentage loss in tensile strength of the leather is proportional to the percentage of the total number of structural linkages broken then the linear relationship shown in figure 6 indicates that the reaction which causes the loss in tensile strength is one of the first order. The straight-line relationship also offers the possibility of making long-term predictions of the durability of leathers.

\section{EFFECT OF VARYING THE HUMIDITY}

The effect of varying the humidity was studied on samples of chestnut- and quebracho-tanned leathers and on similar leathers containing varying amounts of sulfuric acid. The $\mathrm{pH}$ values of the samples ranged from about 5.4 to 1.9. The leathers were aged at $100^{\circ} \mathrm{C}$ for 1 week, and the humidity was controlled by saturating the gas stream with water at a definite temperature. The gas was passed through the saturators, which were held at a constant temperatu e in 


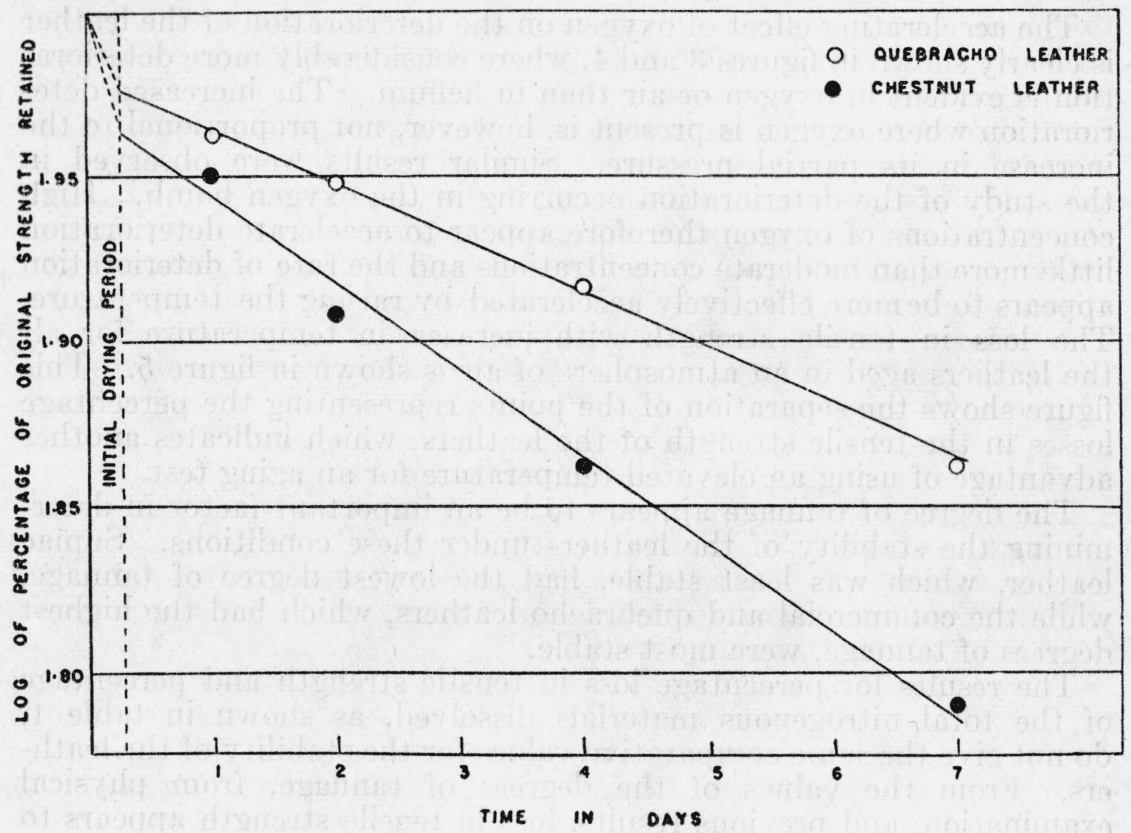

FIGURE 6.-Increase in deterioration of chestnut- and quebracho-tanned leathers with increase in time of aging in air at $110^{\circ} \mathrm{C}$.

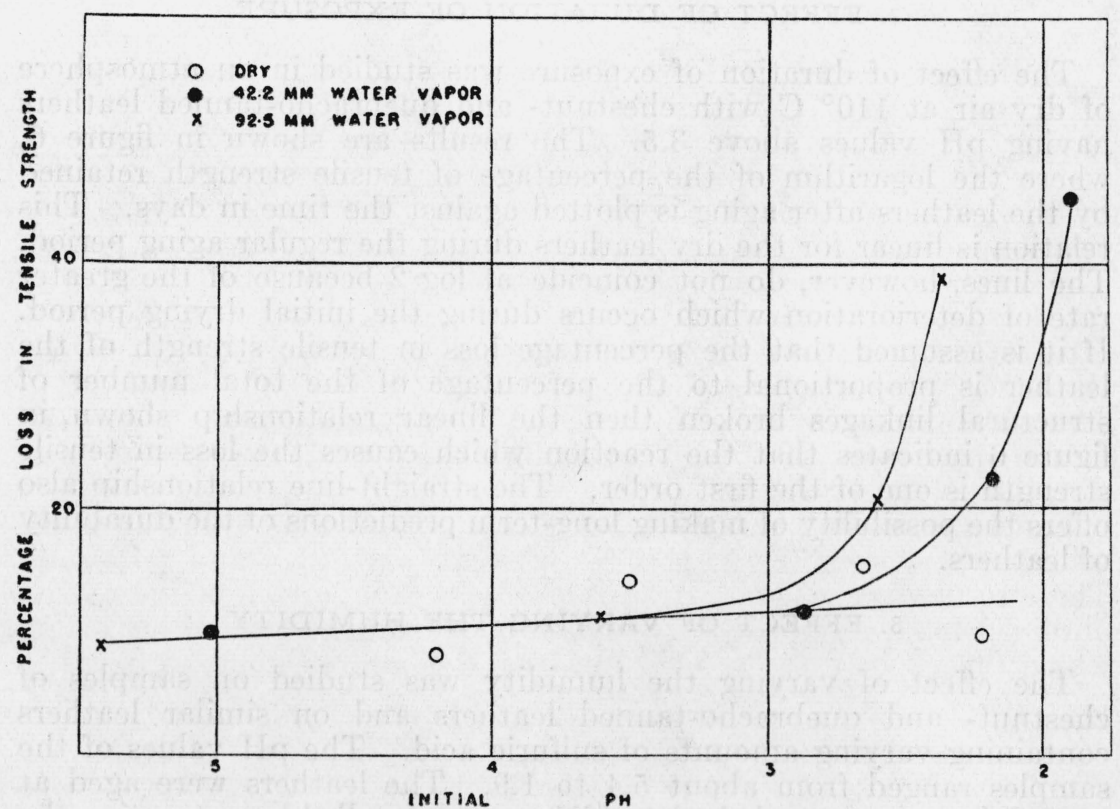

Figure 7.-Effect of increasing the moisture contents of the aging atmosphere for quebracho leather aged in helium at $100^{\circ} \mathrm{C}$. 
the water bath. By raising the temperature of the water bath, the amount of moisture in the gas stream could be increased. In the presence of helium, the pressure of water in the gas stream was varied from approximately 0 to $92.5 \mathrm{~mm}$. The variation over this range was considered sufficient to show the accelerating effect of water vapor. These partial pressures of water in terms of relative humidity at $100^{\circ} \mathrm{C}$ are small but were sufficient to show a considerable effect on the rates of deterioration. The results are shown in table 2 and in figures 7 and 8 . Above $\mathrm{pH} 3$ little or no effect is shown on the

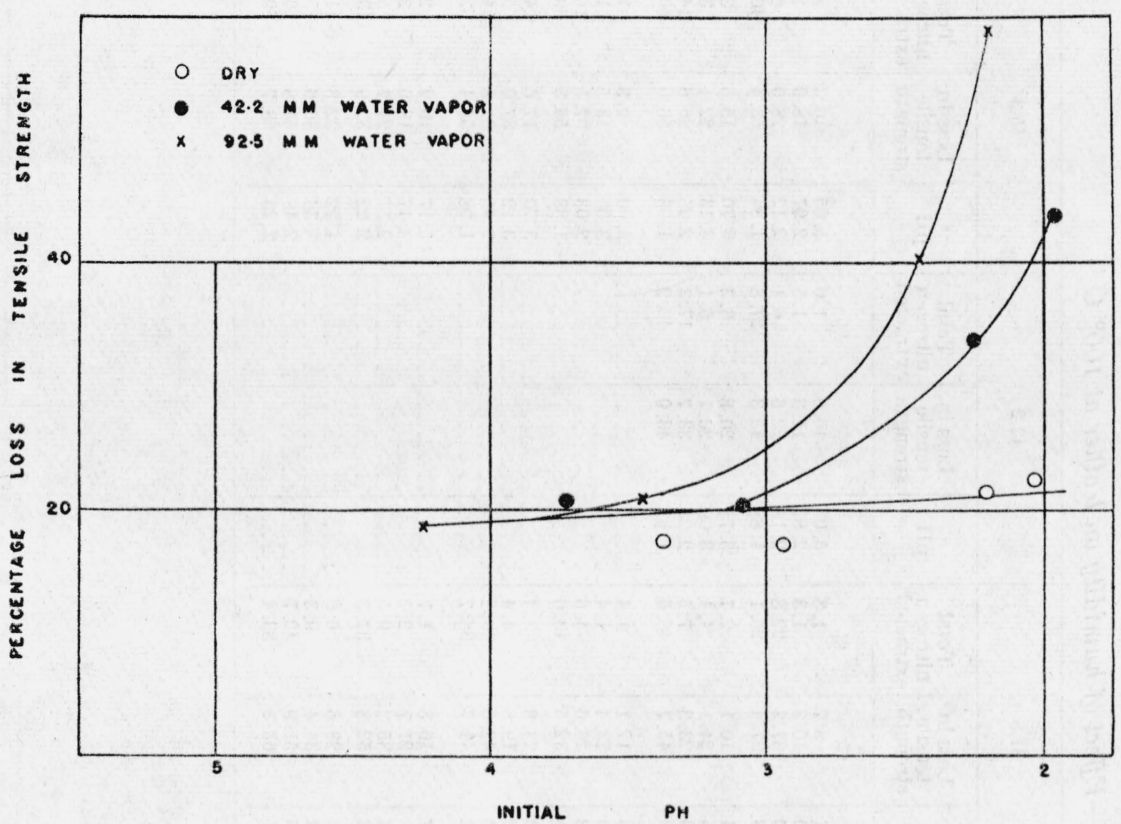

FIGURE 8.-Effect of increasing the moisture contents of the aging atmosphere for chestnut leather aged in helium at $100^{\circ} \mathrm{C}$.

rates of deterioration when the amounts of moisture are increased throughout the range of these experiments. However, below $\mathrm{pH} 3$ a considerable effect may be observed with definite indications that, in the absence of moisture, acid has little effect on the rate of deterioration.

Experiments were also made with air and with oxygen in which the water vapor pressures in the gas streams were 31.8 and $55.3 \mathrm{~mm}$. These results are also shown in table 2. A comparison of the results obtained for helium, air, and oxygen on quebracho-tanned leather in which the vapor pressure of water was $31.8 \mathrm{~mm}$ is shown in figure 9 . 
TABLE 2.-Effect of humidity on leather at $100^{\circ} \mathrm{C}$

\begin{tabular}{|c|c|c|c|c|c|c|c|c|c|c|c|c|c|c|c|c|}
\hline \multicolumn{2}{|c|}{$\begin{array}{l}\text { Vapor pressure of water in } \\
\text { aging atmosphere, } \mathrm{mm}-\end{array}$} & \multicolumn{3}{|c|}{0} & \multicolumn{3}{|c|}{31.8} & \multicolumn{3}{|c|}{42.2} & \multicolumn{3}{|c|}{55.3} & \multicolumn{3}{|c|}{92.5} \\
\hline Leather & $\begin{array}{l}\text { Aging } \\
\text { atmos- } \\
\text { phere }\end{array}$ & $\mathrm{pH}$ & $\begin{array}{l}\text { Loss in } \\
\text { tensile } \\
\text { strength }\end{array}$ & $\begin{array}{c}\text { Total } \\
\text { nitrogen } \\
\text { extracted }\end{array}$ & $\mathrm{pH}$ & $\begin{array}{l}\text { Loss in } \\
\text { tensile } \\
\text { strength }\end{array}$ & $\begin{array}{c}\text { Total } \\
\text { nitrogen } \\
\text { extracted }\end{array}$ & $\mathrm{pH}$ & $\begin{array}{l}\text { Loss in } \\
\text { tensile } \\
\text { strength }\end{array}$ & $\begin{array}{c}\text { Total } \\
\text { nitrogen } \\
\text { ex tracted }\end{array}$ & $\mathrm{pH}$ & $\begin{array}{l}\text { Loss in } \\
\text { tensile } \\
\text { strength }\end{array}$ & $\begin{array}{c}\text { Total } \\
\text { nitrogen } \\
\text { extracted }\end{array}$ & $\mathrm{pH}$ & $\begin{array}{l}\text { Loss in } \\
\text { tensile } \\
\text { strength }\end{array}$ & $\begin{array}{c}\text { Total } \\
\text { nitrogen } \\
\text { extracted }\end{array}$ \\
\hline $\begin{array}{l}\text { Quebracho... } \\
\text { Do } \\
\text { Do } \\
\text { Do... }\end{array}$ & \begin{tabular}{c} 
Helium \\
\hdashline- do \\
- do \\
- do
\end{tabular} & $\begin{array}{l}4.20 \\
\text { 3. } 50 \\
2.65 \\
2.23\end{array}$ & $\begin{array}{r}\% \\
8.2 \\
14.1 \\
15.5 \\
9.9\end{array}$ & $\begin{array}{l}\%_{0.9} \\
0.9 \\
1.3 \\
1.1 \\
1.6\end{array}$ & $\begin{array}{l}5.07 \\
3.00 \\
1.90 \\
1.88\end{array}$ & $\begin{array}{l}\% \\
8.7 \\
10.3 \\
37.3 \\
37.4\end{array}$ & $\begin{array}{r}\% \\
1.3 \\
1.3 \\
22.8 \\
26.1\end{array}$ & $\begin{array}{l}5.03 \\
2.87 \\
2.18 \\
1.88\end{array}$ & $\begin{array}{l}\% \\
10.0 \\
11.3 \\
22.6 \\
45.3\end{array}$ & $\begin{array}{r}\%_{1.0} \\
1.5 \\
6.1 \\
27.8\end{array}$ & $\begin{array}{l}5.05 \\
2.97 \\
2.12 \\
1.84\end{array}$ & $\begin{array}{l}\% \\
10.3 \\
18.9 \\
28.0 \\
53.4\end{array}$ & $\begin{array}{r}\% \\
1.3 \\
1.3 \\
6.8 \\
40.8\end{array}$ & $\begin{array}{l}5.42 \\
3.60 \\
2.60 \\
2.36\end{array}$ & $\begin{array}{l}\% \\
8.8 \\
11.2 \\
20.7 \\
39.0\end{array}$ & $\begin{array}{r}\% \\
1.3 \\
1.1 \\
3.4 \\
11.1\end{array}$ \\
\hline $\begin{array}{l}\text { Chestnut... } \\
\text { Do } \\
\text { Do } \\
\text { Do....... }\end{array}$ & \begin{tabular}{|l|} 
do \\
do \\
do \\
do \\
do
\end{tabular} & $\begin{array}{l}3.37 \\
2.93 \\
2.20 \\
2.03\end{array}$ & $\begin{array}{l}17.3 \\
17.1 \\
21.5 \\
22.4\end{array}$ & $\begin{array}{l}1.8 \\
2.1 \\
2.4 \\
4.4\end{array}$ & $\begin{array}{l}3.74 \\
3.15 \\
2.39 \\
1.90\end{array}$ & $\begin{array}{l}10.1 \\
24.1 \\
23.3 \\
45.7\end{array}$ & $\begin{array}{r}2.7 \\
4.1 \\
7.5 \\
40.5\end{array}$ & $\begin{array}{l}3.73 \\
3.09 \\
2.25 \\
1.97\end{array}$ & $\begin{array}{l}20.8 \\
20.1 \\
33.7 \\
43.9\end{array}$ & $\begin{array}{r}3.3 \\
5.1 \\
17.3 \\
40.2\end{array}$ & $\begin{array}{l}3.70 \\
3.13 \\
2.25 \\
1.93\end{array}$ & $\begin{array}{l}15.6 \\
22.1 \\
26.6 \\
56.0\end{array}$ & $\begin{array}{r}3.8 \\
3.9 \\
14.8 \\
60.3\end{array}$ & $\begin{array}{l}4.25 \\
3.49 \\
2.45 \\
2.19\end{array}$ & $\begin{array}{l}18.5 \\
20.8 \\
40.4 \\
59.1\end{array}$ & $\begin{array}{r}3.7 \\
3.8 \\
25.2 \\
68.2\end{array}$ \\
\hline $\begin{array}{l}\text { Quebracho... } \\
\text { Do } \\
\text { Do } \\
\text { Do }\end{array}$ & $\begin{array}{l}\text { Air } \\
\text { do } \\
\text { do } \\
\text { do }\end{array}$ & & & & $\begin{array}{l}5.13 \\
3.50 \\
2.22 \\
2.05\end{array}$ & $\begin{array}{l}12.1 \\
23.4 \\
26.6 \\
32.5\end{array}$ & $\begin{array}{r}1.4 \\
1.4 \\
4.6 \\
13.0\end{array}$ & & & & $\begin{array}{l}5.00 \\
3.00 \\
2.03 \\
1.88\end{array}$ & $\begin{array}{r}9.3 \\
13.5 \\
37.5 \\
55.3\end{array}$ & $\begin{array}{r}1.5 \\
1.5 \\
16.9 \\
39.5\end{array}$ & & & \\
\hline $\begin{array}{l}\text { Chestnut... } \\
\text { Do } \\
\text { Do } \\
\text { Do }\end{array}$ & 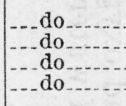 & & & & $\begin{array}{l}4.03 \\
3.32 \\
2.33 \\
2.12\end{array}$ & $\begin{array}{l}23.8 \\
19.8 \\
42.6 \\
44.7\end{array}$ & $\begin{array}{r}3.4 \\
4.4 \\
17.2 \\
38.7\end{array}$ & & & - & $\begin{array}{l}\text { 3. } 70 \\
3.12 \\
2.45 \\
1.98\end{array}$ & $\begin{array}{l}17.6 \\
37.0 \\
31.8 \\
55.4\end{array}$ & $\begin{array}{r}4.0 \\
5.8 \\
14.6 \\
62.5\end{array}$ & & & \begin{tabular}{l}
- \\
$-\because$ \\
\hdashline \\
- \\
-
\end{tabular} \\
\hline $\begin{array}{c}\text { Quebracho... } \\
\text { Do } \\
\text { Do. } \\
\text { Do........ }\end{array}$ & $\begin{array}{c}\text { Oxygen } \\
\text { do } \\
\text { do do } \\
- \text { do } \\
\end{array}$ & ....... & & $-\ldots$ & $\begin{array}{l}5.17 \\
3.37 \\
2.23 \\
1.93\end{array}$ & $\begin{array}{l}16.3 \\
21.7 \\
35.2 \\
52.3\end{array}$ & $\begin{array}{r}1.7 \\
2.2 \\
9.5 \\
37.3\end{array}$ & & - & $\ldots$ & $\begin{array}{l}5.17 \\
3.47 \\
2.57 \\
2.22\end{array}$ & $\begin{array}{l}19.2 \\
18.6 \\
24.7 \\
32.9\end{array}$ & $\begin{array}{r}2.4 \\
2.3 \\
5.7 \\
13.4\end{array}$ & & & - \\
\hline $\begin{array}{l}\text { Chestnut... } \\
\text { Do } \\
\text { Do } \\
\text { Do }\end{array}$ & \begin{tabular}{l} 
do do \\
\hdashline do \\
\hdashline do \\
\hdashline do
\end{tabular} & - & - & (1) & $\begin{array}{l}3.93 \\
3.33 \\
2.35 \\
2.07\end{array}$ & $\begin{array}{l}28.6 \\
34.4 \\
51.9 \\
63.3\end{array}$ & $\begin{array}{r}6.6 \\
9.3 \\
42.7 \\
83.4\end{array}$ & - & -.. & . & $\begin{array}{l}\text { 4. } 22 \\
\text { 3. } 36 \\
2.48 \\
2.25\end{array}$ & $\begin{array}{l}32.3 \\
36.6 \\
54.8 \\
58.7\end{array}$ & $\begin{array}{l}11.5 \\
15.0 \\
56.1 \\
80.5\end{array}$ & & & - \\
\hline
\end{tabular}


The accelerating effect of the oxygen is shown here throughout the entire $\mathrm{pH}$ range. The differences between the percentage losses in tensile strength in the presence of oxygen and in the presence of helium under these conditions are approximately the same as those under the dry conditions. These results are similar to those obtained

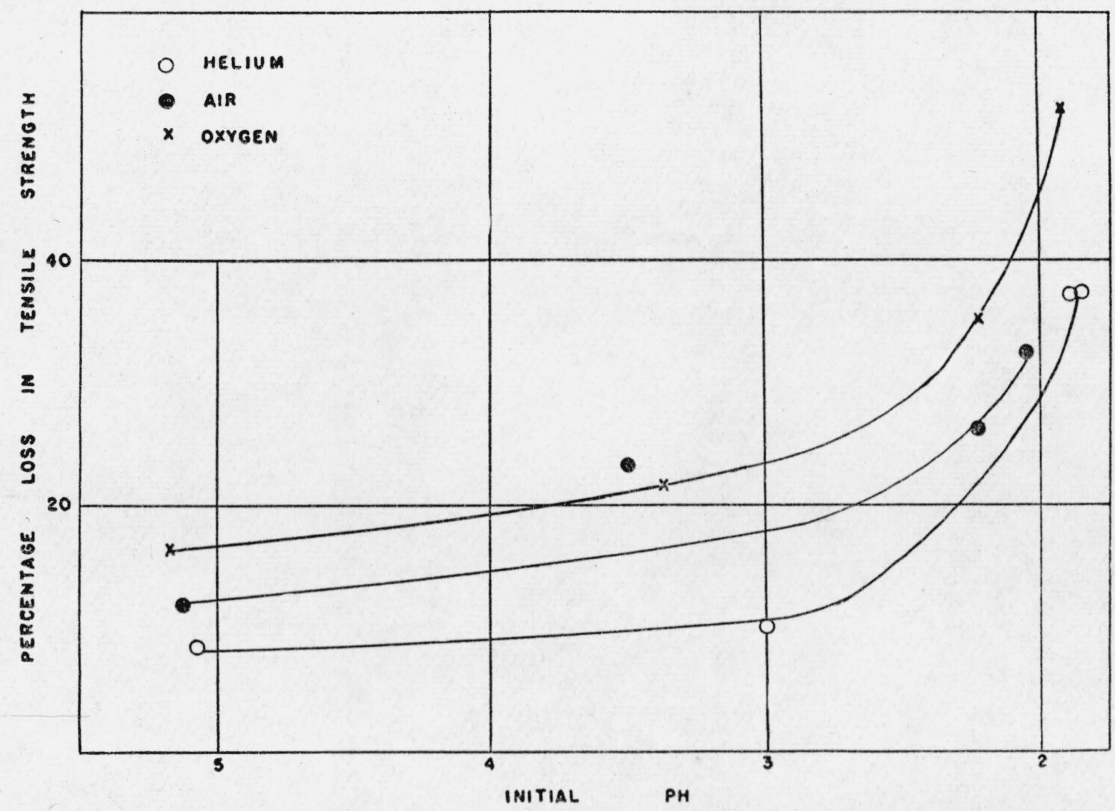

FIGURE 9.-Effect of aging atmosphere of helium, air, and oxygen containing 31.8 $m m$ of water vapor on leather at different $\mathrm{pH}$ values.

under normal aging conditions with respect to change in rate of deterioration with decrease in $\mathrm{pH}$.

\section{CONCLUSIONS}

Deterioration of leather as measured by percentage losses in tensile strength and percentage of the total nitrogenous materials extractable is accelerated by oxygen at elevated temperatures. Increased temperature alone, as shown in an inert helium atmosphere, also accelerates deterioration. The effect of humidity on the rate of deterioration is greatest below pH 3 .

These results indicate that the most important features of an accelerated-aging test for leather are aging in an oxidizing atmosphere containing moisture, at an elevated temperature. This is the same principle as that involved in the oxygen-bomb test. The method of applying the test described in this paper is however believed to be an improvement over the oxygen-bomb test, since it permits a more convenient control of all the factors involved.

Washington, May 21, 1940. 